UDC 519.626

DOI: $10.32626 / 2308-5916.2019-20.99-103$

S. Soloviov, $\mathrm{PhD}$,

O. Bandurka

National Technical University of Ukraine

«Igor Sikorsky Kyiv Polytechnic Institute», Kyiv

\title{
MODELLING THE OPTIMAL SCHEMES OF POPULATION VACCINATION USING EPIDEMIOLOGICAL DATA
}

Considered creation of a mathematical and computer model of the various infectious diseases and epidemics' spread problem. The developed system uses an epidemiological SISV computer model. The proposed model gives an opportunity to determine the optimal individual and social costs for vaccine prophylaxis The article analyses the positivity of such a model under the proposed vaccination strategy. SISV (Susceptible-Infectious-Susceptible-Vaccinated)-model, where infection does not confer immunity (or there is waning immunity) with inclusion of vaccination. The software uses epidemiological models that allow us to explore the process of spreading infectious diseases, to make a forecast for the future, to determine the effectiveness of vaccine prophylaxis, to select optimal vaccination schemes using epidemiological data. Due to the use of epidemiological models a timely prevention of infectious diseases epidemics is possible.

Keywords: computer modelling of the optimal schemes, epidemiological model, SISV-model.

Introduction. The problem of the spread of various infectious diseases and epidemics is important for all humanity. Rotavirus infection (RVI) is the leading cause of acute viral gastroenteritis among young children and high infant morbidity and mortality worldwide. To reduce the rate of infection, vaccine prophylaxis is used. In the context of limited resources, it is not possible to carry out vaccination of the entire population, therefore the problem of determination of the optimal social and individual costs for vaccination and treatment remains relevant.

Considering that, there are many approaches to solving vaccinerelated problems at the moment, but various diseases have some peculiarities that need to be taken into account when developing epidemiological models. That is why modern practice has not developed universal software or computer model for monitoring the effectiveness of vaccine prophylaxis. Because of the considerable variety and complexity of the parameters none of the existing software products is a universal means.

The developed computer modelling system uses an epidemiological SISV model (Susceptible-Infectious-Susceptible-Vaccinated-model).

Constructing an epidemiological model. The basic principle of constructing an epidemiological model for RVI: the whole population is 
divided into several categories; the model is a dynamical system that changes in time, therefore, when passing a certain time period, a part of the population moves from one category to another. In epidemiological models there are the following categories:

- $\mathrm{S}$ - susceptible individuals: susceptible to infection;

- I - infected persons: infected with an infectious disease being of interest, capable of infecting others;

- V - vaccinated persons who have received immunity, are inaccessible to infection.

The transition of persons from one category of population to another is characterized by parameters, for example: the power of the infection, speed of healing, birthrate, mortality, migration rate, etc. The power of infection $\lambda$ is the probability of a certain person`s being infected at a certain time. The speed of healing $\gamma$ is the probability of a certain person's being cured at a certain time.

The use of the SIS computer model presupposes that infected individuals (I) recover when some time passes and become susceptible to the disease again (Figure 1).

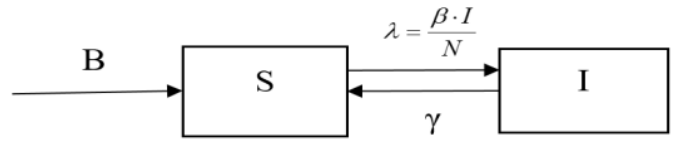

Fig. 1. SIS-model

where: $B-$ birthrate, $N-$ the whole population, $S-$ susceptible persons, $I$ - infected persons, $\lambda$ - infection power, $\beta$ - parameter of the pathogen transmission, $\gamma$ - speed of healing (loss of infectiousness).

Parameters of the model, like the system as a whole, can be dynamic. The SIS mathematical model can be described using the system of difference equations [2]:

$$
\left\{\begin{array}{l}
S_{t+1}=B_{t}+S_{t}-\frac{\beta_{t} \cdot I_{t}}{N_{t}} \cdot S_{t}+\gamma_{t} \cdot I_{t} \\
I_{t+1}=I_{t}+\frac{\beta_{t} \cdot I_{t}}{N_{t}} \cdot S_{t}-\gamma_{t} \cdot I_{t},
\end{array}\right.
$$

where: $t$ - period of time.

If vaccination being added to the SIS-model, we will get the SISVmodel (Figure 2)

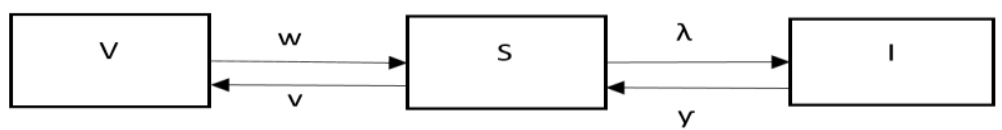

Fig 2. SISV-model 
where: $V$ - vaccinated persons, $v-$ population coverage by vaccination, $w$ - decrease of immunity.

Mathematical model can be described by the system of equations:

$$
\left\{\begin{array}{c}
S_{t+1}=S_{t}-v_{t} \cdot S_{t}+w_{t} \cdot V_{t}-\lambda_{t} \cdot S_{t}+\gamma_{t} \cdot I_{t} ; \\
I_{t+1}=I_{t}+\lambda_{t} \cdot S_{t}-\gamma_{t} \cdot I_{t} ; \\
V_{t+1}=V_{t}+v_{t} \cdot S_{t}-w_{t} \cdot V_{t} .
\end{array}\right.
$$

Thus, using the SISV-model, one can determine the optimal scheme of vaccination for the population to prevent from the spreading of infectious diseases.

The software uses epidemiological models that allow us to explore the process of spreading infectious diseases, to make a forecast for the future, to determine the effectiveness of vaccine prophylaxis, to select optimal vaccination schemes using epidemiological data [1]. Due to the use of epidemiological models a timely prevention of infectious diseases epidemics is possible.

The system consists of three software modules: data access module, business logic module and presentation module. The data access module is in charge of reading, processing and storing of incoming epidemiological data. The processing of incoming epidemiological data is necessary to eliminate the excess data and to automate the process of collecting and calculating statistics [3].

The module of business logic carries out the construction of epidemiological models, making a forecast for the future. The module defines optimal vaccination schemes depending on incoming epidemiological data.

The presentation module uses a graphical user interface to output the obtained results of the system work (Figure 3).

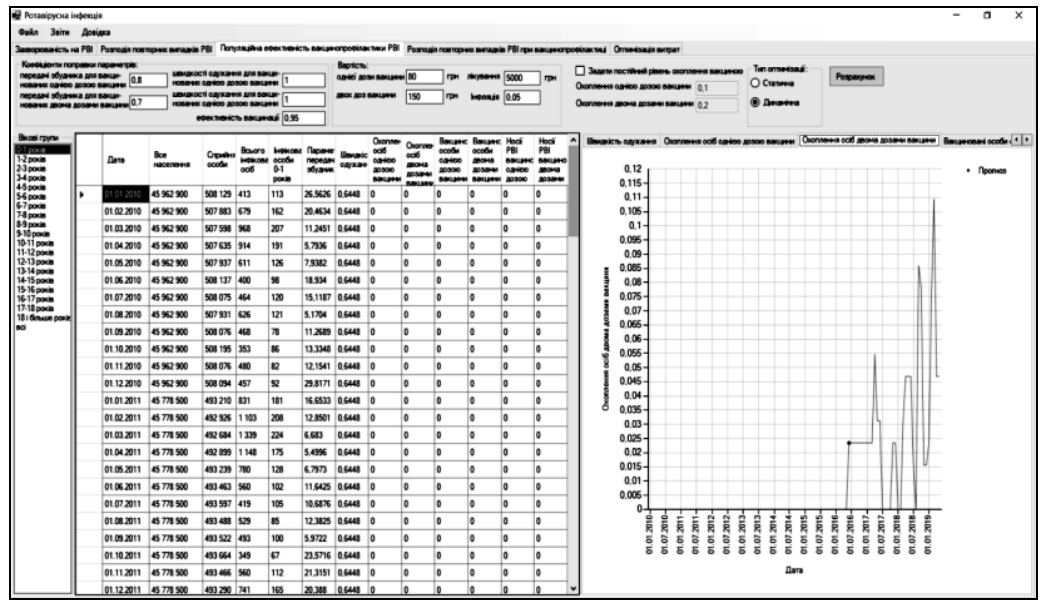

Fig. 3. The main window of the developed system 
The developed system gives an opportunity to determine the optimal individual and social costs for vaccine prophylaxis (Figure 4).

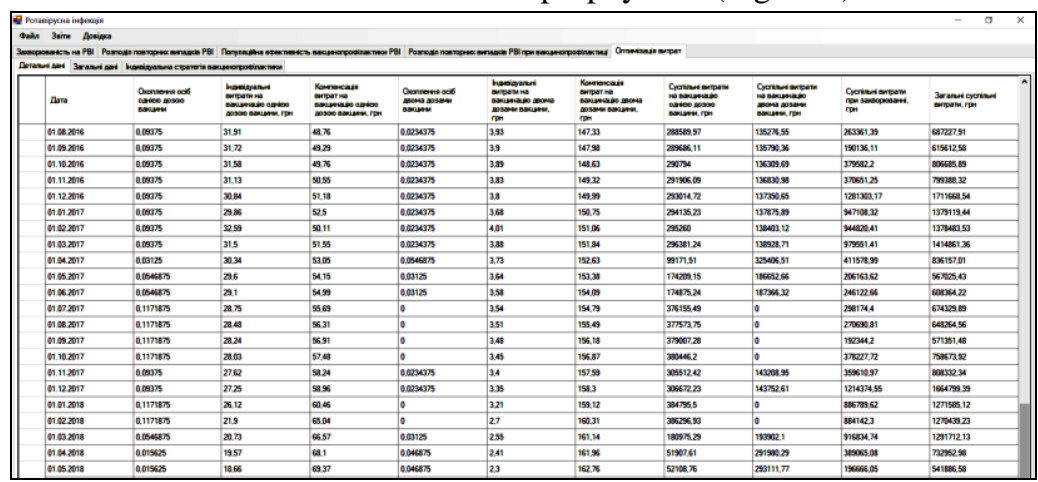

Fig. 4. Optimization of costs

UML use case diagram shows the possible options available to users of the system (Figure 5).

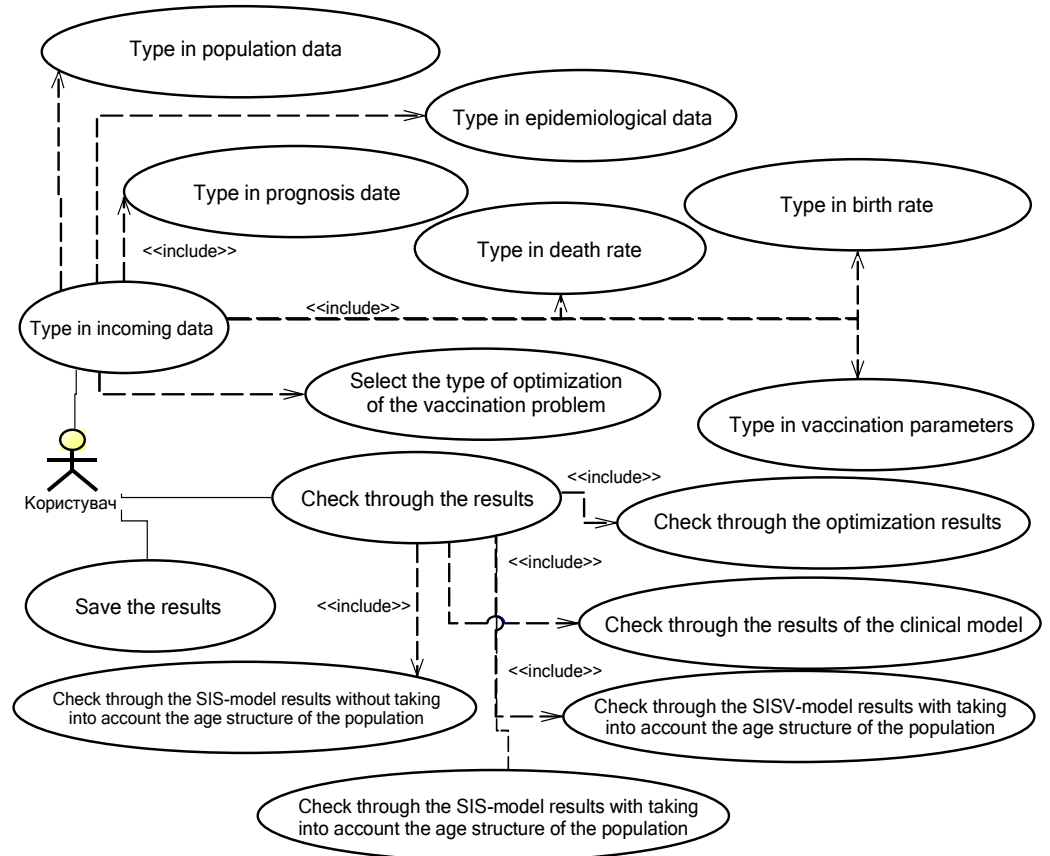

Fig. 5. Diagram of the precedents of the developed system

The developed computer modelling system can be used for the study of RVI, the compilation of morbidity prognosis, the selection of optimal 
vaccination schemes, as well as the determination of the costs for treatment and vaccine prophylaxis.

Conclusions. Thus, in the article, considered the developed computer modelling system can be used for the study of RVI, the compilation of morbidity prognosis, the selection of optimal vaccination schemes, as well as the determination of the costs for treatment and vaccine prophylaxis.

\section{References:}

1. Tassier T. The Economics of Epidemiology / T. Tassier. - Berlin : Springer Science \& Business Media, 2013. - P. 3-24.

2. Hethcote W. Three Basic Epidemiological Models / W. Hethcote. - Berlin : Springer, 1989. - P. 119-137.

3. Brauer F. Mathematical Models in Population Biology and Epidemiology / F. Brauer. — New York : Springer, 2001. — P. 3-120.

\section{МОДЕЛЮВАННЯ ОПТИМАЛЬНИХ СХЕМ ВАКЦИНАЦІЇ НАСЕЛЕННЯ 3 ВИКОРИСТАННЯМ ЕПІДЕМІОЛОГІЧНИХ ДАНИХ}

Розглянуто створення математичної та комп'ютерної моделі в проблемі поширення різних інфекційних захворювань та епідемій. Розроблена система комп'ютерного моделювання використовує епідеміологічну SISV-модель. Ця модель визначає оптимальну схему вакцинації населення. У статті проаналізовано позитивність такої моделі у запропонованій стратегії вакцинації. SISV (сприйнятливий-інфекційний, сприйнятливий до вакцинації)-модель, де інфекція не надає імунітету (або є зменшенням до імунітету) з виключенням вакцинації. У програмному забезпеченні використовуються епідеміологічні моделі, які дозволяють дослідити процес поширення інфекційних захворювань, зробити прогноз на майбутнє, визначити ефективність вакцинопрофілактики, вибрати оптимальні схеми вакцинації з використанням епідеміологічних даних. Завдяки використанню епідеміологічних моделей можлива своєчасна профілактика епідемій інфекційних захворювань.

Ключові слова: комп'ютерне моделювання оптимальної схеми, епідеміологічна модель, SISV-модель.

Отримано: 28.08.2019 